\title{
Sources of Resistance to Tobacco streak virus in Wild Arachis (Fabaceae: Papilionoidae) Germplasm
}

\author{
G. Kalyani, A. S. Reddy, and P. Lava Kumar, International Crops Research Institute for the Semi-Arid Tropics \\ (ICRISAT), Patancheru 502 324, Andhra Pradesh, India; R. D. V. J. Prasada Rao, National Bureau of Plant Ge- \\ netic Resources, Rajendranagar 560 065, Hyderabad, India; and R. Aruna, F. Waliyar, and S. N. Nigam, ICRI- \\ SAT, India
}

\begin{abstract}
Kalyani, G., Reddy, A. S., Kumar, P. L., Rao, R. D. V. J. P., Aruna, R., Waliyar, F., and Nigam, S. N. 2007. Sources of resistance to Tobacco streak virus in wild Arachis (Fabaceae: Papilionoidae) germplasm. Plant Dis. 91:1585-1590.
\end{abstract}

Stem necrosis disease caused by Tobacco streak virus (TSV), first recognized in 2000, has emerged as a potential threat to peanut (Arachis hypogaea) in southern states of India. The virus induces severe necrosis of shoots leading to death of the plant, and plants that survive are malformed, with severe reduction in pod yield. All the currently grown peanut cultivars in India are highly susceptible to the virus. Therefore, wild relatives of peanut were evaluated to identify potential sources of resistance to TSV infection. In all, 56 germplasm accessions from 20 wild Arachis spp. in four sections (Arachis, Erectoides, Procumbente, and Rhizomatosae), along with susceptible peanut cultivars (JL 24 and K 1375), were evaluated for resistance to TSV under greenhouse conditions using mechanical sap inoculations. Systemic virus infection, determined by enzyme-linked immunosorbent assay (ELISA), in the test accessions ranged between 0 and 100\%. Twenty-four accessions in section Arachis that had 0 to 35\% systemically infected plants were retested, and systemic infection was not detected in eight of these accessions in repeated trials in the greenhouse. These are International Crops Research Institute for the Semi-Arid Tropics groundnut (ICG) accession nos. 8139, 8195, 8200, 8203, 8205, and 11550 belonging to A. duranensis; ICG 8144 belonging to A. villosa; and ICG 13210 belonging to A. stenosperma. Even though the resistant accessions had 0 to $100 \%$ TSV infection in inoculated leaves, TSV was not detected in the subsequently emerged leaves. This is the first report of TSV resistance in Arachis spp. The eight TSV resistant accessions are cross compatible with A. hypogaea for utilization in breeding for stem necrosis disease resistance.

Additional keywords: Ilarvirus, thrips

Peanut or groundnut (Arachis hypogaea L.) is an important oil, food, and forage legume grown on 6.72 million ha in India (5). Nearly $11 \%$ of the total peanut production in India comes from the Anantapur district of Andhra Pradesh state, which has the distinction of being the world's largest peanut-producing region, with more than $70 \%$ of the cultivated area devoted to peanut production. The stem necrosis disease caused by Tobacco streak virus (TSV; genus Ilarvirus and family Bromoviridae)

Corresponding author: P. Lava Kumar

E-mail: p.lavakumar@cgiar.org

Current address of P. Lava Kumar: International Institute of Tropical Agriculture (IITA), P.M.B. 5320, Ibadan, Nigeria

Address for reprint request: f.waliyar@cgiar.org

Accepted for publication 8 July 2007.

doi:10.1094/PDIS-91-12-1585

(C) 2007 The American Phytopathological Society on peanut first was noticed in Anantapur district in $2000(19,23)$. The virus epidemic that year affected 225,000 ha, resulting in yield losses valued at US\$65 million (23). Since then, the TSV incidence has been monitored regularly in Andhra Pradesh and the adjoining regions in Karnataka state, with incidence ranging from 0 to $15 \%$ in 2002 to 0 to $3 \%$ in 2003 and 1 to $80 \%$ in $2004(12,20)$. TSV infection at early stages of plant growth results in severe necrotic symptoms on leaves, petioles, and stems leading to premature death of the plant. Virus infection at later stages of plant growth ( $>40$ days old) results in partial necrosis on leaves and main stem, proliferation of axillary buds, and drastic reductions in pod yield. Some plants may not become necrotic, but are severely stunted, having small leaves with or without chlorosis (23). The TSV isolate from peanut is serologically related to the TSV-WC strain, and shares high levels of nucleotide sequence identity ( 85 to $90 \%$ ) with this strain in the movement and coat protein gene sequences $(1,23)$. Three species of thrips, Megalurothrips usitatus, Frankliniella schultzei, and Scirtothrips dorsalis, transmitted the virus to peanut, apparently by mechanical inoculation in the presence of infected pollen rather than as direct vectors $(20,25)$. The virus is not seedborne in peanut, and cleistogamous flowering prevents further spread of virus from peanut.

Since the first identification of TSV in 2000 , the virus has been found on several vegetable and oilseed crops in Andhra Pradesh, Karnataka, Maharashtra, and Tamil Nadu states in India $(7,11,12)$. The virus causes asymptomatic infections in several common weed species, including Parthenium hysterophorus, Ageratum conyzoides, and Corchorus trilocularis, whose pollen is a major source of TSV, and these plants also harbor thrips $(20,21)$. Disease incidence in peanut and other susceptible crops is increasing at an alarming rate and is very high during lowrainfall and drought years. None of the peanut cultivars currently grown in India has resistance to TSV infection. Management strategies based on cultural practices, such as seed treatment with imidacloprid to control the thrips vector, barrier crops with fast-growing tall cereals to prevent insect movement, removal of TSVsusceptible weed hosts, and maintaining optimal plant density were shown to reduce disease incidence, but are seldom practiced under subsistence agriculture systems (21). In our earlier studies, none of the 150 peanut cultivars and advanced breeding lines evaluated for TSV resistance by sap inoculation were resistant $(8,21)$. Symptom expression was delayed in three breeding lines, International Crops Research Institute for the Semi-Arid Tropics (ICRISAT) groundnut variety (ICGV) nos. 92267, 99029, and 01276, but they succumbed under high disease pressure (21). This situation necessitated a search for sources of durable resistance in wild Arachis germplasms, which are reported to carry genes for many agronomic traits as well as resistance genes against several pathogens and insect pests $(9,14)$. Therefore, this study was conducted to evaluate 56 germplasm accessions from 20 wild Arachis spp. in four sections for TSV resistance under greenhouse conditions, and reports the occurrence of resistance to TSV in some accessions of the section Arachis that can be introgressed into elite peanut cultivars through interspecific breeding programs. 


\section{MATERIALS AND METHODS}

Seed material and plant growth conditions. Fifty-six wild Arachis accessions were obtained from the R. S. Paroda Gene Bank at ICRISAT, Patancheru, India (Table 1). Peanut cvs. JL 24 and K 1375 were used as susceptible controls. The 56 wild Arachis accessions were tested in batches from June to November 2004, along with susceptible controls. Promising accessions selected from this trial were reevaluated from September to November 2005, and again from May to July 2006, under similar plant growth conditions. Seed of each accession were treated with thiram (Chemet Chemicals Ltd., Gujarat, India) (3 $\mathrm{mg} \mathrm{g}^{-1}$ of seed), sown in 22-cm-diameter plastic pots filled with sterilized Alfisols, and maintained in an insect-proof greenhouse (80\% humidity and 25 to $30^{\circ} \mathrm{C}$ under natural light). The experiments were arranged in a randomized block design with two replications, with each pot containing three to seven seedlings considered as a replication.

Virus culture and inoculation. The TSV culture used in the study was isolated from diseased peanut plants collected in Anantapur during 2000, and subsequently established on Phaseolus vulgaris cv. French bean, which was lyophilized and preserved at $-70^{\circ} \mathrm{C}(20)$. A week before inoculation, sap extracts from the lyophilized leaf material were inoculated onto cotyledons of French bean as described by Reddy et al. (23). Symptomatic leaves of these plants were ground in $0.05 \mathrm{M}$ phosphate buffer $(1: 10 \mathrm{wt} / \mathrm{vol})$ containing $0.15 \%$ monothioglycerol and the inoculum was applied onto Carborundum-dusted upper leaf surfaces of all the three quadrifoliate leaves of wild Arachis and control plants at a three-leaf growth stage. Inoculated leaves were washed with distilled water and kept in the dark for 12 to $14 \mathrm{~h}$. Plants were monitored for TSV infection at 2-week intervals until the plants were 3 months old.

Detection of TSV. Polyclonal antibodies raised to TSV were used to assay all the inoculated and subsequently emerged leaves of all test plants by direct-antigen coating enzyme-linked immunosorbent assay (DAC-ELISA) as described by Hobbs et al. (6). Briefly, test leaves were extracted in $0.1 \mathrm{M}$ carbonate buffer, $\mathrm{pH}$ $9.5,(1: 20 \mathrm{wt} / \mathrm{vol})$, and $100 \mu \mathrm{l}$ were loaded into wells of ELISA plates. TSV antiserum was used at a 1:15,000 dilution after crossadsorption with healthy peanut leaf extract $(1: 20 \mathrm{wt} / \mathrm{vol})$. Alkaline phosphatase (ALP)-labeled goat anti-rabbit immunoglobulin Gs (Sigma-Aldrich, St. Louis) at 1:5,000 dilution and paranitrophenyl phosphate at $0.5 \mathrm{mg} \mathrm{ml}^{-1}$ in $10 \%(\mathrm{vol} / \mathrm{vol})$ diethanolamine buffer, $\mathrm{pH} 9.8$, were used to detect antigen-antibody complexes. Optical density at $405 \mathrm{~nm}$ was measured in a Titertek Multiskan ELISA reader after 60 min. Readings were considered virus positive if the absorbance values of samples
Table 1. Responses of accessions of wild Arachis inoculated with Tobacco streak virus (TSV) under greenhouse conditions during June to November 2004

\begin{tabular}{|c|c|c|c|}
\hline \multirow[b]{2}{*}{$\begin{array}{l}\text { Section, species } \\
\text { (ICG no. })^{\mathbf{b}}\end{array}$} & \multirow[b]{2}{*}{$\begin{array}{l}\text { No. of plants } \\
\text { tested }\end{array}$} & \multicolumn{2}{|c|}{ Mean percent infection ${ }^{a}$} \\
\hline & & $\begin{array}{l}\text { Inoculated } \\
\text { leaves }\end{array}$ & $\begin{array}{c}\text { Subsequently produced } \\
\text { leaves }\end{array}$ \\
\hline \multicolumn{4}{|l|}{$\overline{\text { Arachis batizocoi }}$} \\
\hline 8124 & 6 & $0(0.01)$ & $16.5(0.17)$ \\
\hline 8209 & 9 & $0(0.01)$ & $0(0.01)$ \\
\hline 8210 & 7 & $100(1.38)$ & $100(1.38)$ \\
\hline 13160 & 11 & $91(1.14)$ & $100(1.34)$ \\
\hline \multicolumn{4}{|l|}{ A. benensis } \\
\hline 13257 & 15 & $13(0.13)$ & $13(0.13)$ \\
\hline \multicolumn{4}{|l|}{ A. cardenasii } \\
\hline 11559 & 8 & $75(0.85)$ & $75(0.85)$ \\
\hline 11561 & 7 & $71(0.79)$ & $71(0.79)$ \\
\hline 11562 & 5 & $25(0.27)$ & $25(0.27)$ \\
\hline 11563 & 12 & $83(0.98)$ & $83(0.98)$ \\
\hline 11564 & 6 & $16.5(0.17)$ & $16.5(0.17)$ \\
\hline 11566 & 10 & $20(0.2)$ & $10(0.11)$ \\
\hline 12165 & 10 & $0(0.01)$ & $0(0.01)$ \\
\hline \multicolumn{4}{|l|}{ A. correntina } \\
\hline 8132 & 14 & $79(0.91)$ & $79(0.91)$ \\
\hline \multicolumn{4}{|l|}{ A. duranensis } \\
\hline 8123 & 10 & $0(0.01)$ & $10(0.11)$ \\
\hline 8139 & 10 & $10(0.11)$ & $0(0.01)$ \\
\hline 8195 & 8 & $0(0.01)$ & $0(0.01)$ \\
\hline 8196 & 8 & $88(1.08)$ & $88(1.08)$ \\
\hline 8199 & 10 & $100(1.35)$ & $70(0.78)$ \\
\hline 8200 & 10 & $0(0.01)$ & $0(0.01)$ \\
\hline 8201 & 9 & $89(1.10)$ & $89(1.10)$ \\
\hline 8202 & 6 & $100(1.40)$ & $83(098)$ \\
\hline 8203 & 10 & $0(0.01)$ & $30(0.31)$ \\
\hline 8204 & 5 & $100(1.41)$ & $100(1.41)$ \\
\hline 8205 & 10 & $0(0.01)$ & $0(0.01)$ \\
\hline 8208 & 6 & $50(0.52)$ & $100(1.40)$ \\
\hline 11550 & 10 & $0(0.01)$ & $0(0.01)$ \\
\hline 11552 & 5 & $0(0.01)$ & $0(0.01)$ \\
\hline 11554 & 8 & $63(0.68)$ & $38(0.39)$ \\
\hline 13200 & 7 & $46(0.49)$ & $46(0.49)$ \\
\hline \multicolumn{4}{|l|}{ A. helodes } \\
\hline 8952 & 6 & $83(0.98)$ & $67(0.73)$ \\
\hline \multicolumn{4}{|c|}{ A. kempff-mercadoi } \\
\hline 8959 & 5 & $100(1.41)$ & $80(0.93)$ \\
\hline \multicolumn{4}{|l|}{ A. kuhlmannii } \\
\hline 8192 & 5 & $80(0.93)$ & $100(1.41)$ \\
\hline \multicolumn{4}{|l|}{ A. ipaensis } \\
\hline 8206 & 7 & $100(1.38)$ & $71(0.79)$ \\
\hline \multicolumn{4}{|l|}{ A. monticola } \\
\hline 8135 & 13 & $100(1.32)$ & $85(1.02)$ \\
\hline 8197 & 6 & $100(1.40)$ & $100(1.40)$ \\
\hline 8198 & 11 & $100(1.34)$ & $100(1.34)$ \\
\hline A. stenosperma & & & \\
\hline 8126 & 5 & $80(0.93)$ & $40(0.41)$ \\
\hline 8137 & 6 & $0(0.01)$ & $16.5(0.17)$ \\
\hline 13171 & 7 & $16.5(0.17)$ & $0(0.01)$ \\
\hline 13172 & 9 & $45(0.47)$ & $12.5(0.13)$ \\
\hline 13188 & 7 & $86(1.04)$ & $86(1.04)$ \\
\hline 13210 & 6 & $0(0.01)$ & $0(0.01)$ \\
\hline 13223 & 10 & $33.5(0.37)$ & $33.5(0.37)$ \\
\hline 13233 & 6 & $16.5(0.17)$ & $33(0.34)$ \\
\hline A. villosa & & & \\
\hline 8144 & 7 & $54(0.59)$ & $0(0.01)$ \\
\hline 13168 & 7 & $12.5(0.13)$ & $0(0.01)$ \\
\hline 13259 & 8 & $25(0.25)$ & $38(0.39)$ \\
\hline A. rigonii & & & \\
\hline 8186 & 9 & $56(0.59)$ & $22(0.22)$ \\
\hline Arachis (species & & & \\
\hline 4982 & 12 & $100(1.39)$ & $58(0.62)$ \\
\hline Procumbentes al & & & \\
\hline 8128 & 12 & $100(1.33)$ & $92(1.12)$ \\
\hline & & & (continued on next page) \\
\hline
\end{tabular}

${ }^{a}$ Percent infection based on virus detection in enzyme linked-immunosorbent assay. Numbers in parenthesis $=$ angular transformed values.

${ }^{\mathrm{b}}$ ICG = International Crops Research Institute for the Semi-Arid Tropics groundnut accession number.

${ }^{c} \mathrm{SEM}=$ standard error of the mean.

${ }^{\mathrm{d}} \mathrm{LSD}=$ least significant difference. 
Table 1. (continued from preceding page)

\begin{tabular}{|c|c|c|c|}
\hline \multirow[b]{2}{*}{$\begin{array}{l}\text { Section, species } \\
{\text { (ICG no. })^{b}}^{\text {ICG }}\end{array}$} & \multirow[b]{2}{*}{$\begin{array}{l}\text { No. of plants } \\
\text { tested }\end{array}$} & \multicolumn{2}{|c|}{ Mean percent infection ${ }^{a}$} \\
\hline & & $\begin{array}{l}\text { Inoculated } \\
\text { leaves }\end{array}$ & $\begin{array}{c}\text { Subsequently produced } \\
\text { leaves }\end{array}$ \\
\hline 8129 & 5 & $40(0.41)$ & $40(0.41)$ \\
\hline \multicolumn{4}{|l|}{ P. rigonii } \\
\hline 8904 & 5 & $60(0.64)$ & $100(1.41)$ \\
\hline \multicolumn{4}{|l|}{ P. kretschmeri } \\
\hline 8191 & 8 & $100(1.37)$ & $88(1.08)$ \\
\hline \multicolumn{4}{|c|}{ Erectoides paraguariensis } \\
\hline 8141 & 14 & $100(1.31)$ & $86(1.04)$ \\
\hline \multicolumn{4}{|l|}{ E. stenophylla } \\
\hline 8215 & 10 & $100(1.35)$ & $100(1.35)$ \\
\hline \multicolumn{4}{|c|}{ Rhizomatosae glabrata } \\
\hline 8937 & 9 & $100(1.36)$ & $100(1.36)$ \\
\hline \multicolumn{4}{|c|}{ Control (A. hypogaea) } \\
\hline JL 24 & 10 & $40(0.41)$ & $100(1.41)$ \\
\hline K 1375 & 10 & $50(0.53)$ & $70(0.79)$ \\
\hline $\operatorname{SEM}( \pm)^{\mathrm{c}}$ & $\ldots$ & -0.0624 & -0.0582 \\
\hline $\operatorname{LSD}(P=5 \%)^{\mathrm{d}}$ & $\ldots$ & -0.175 & -0.163 \\
\hline
\end{tabular}

Table 2. Response of selected wild Arachis accessions for resistance to Tobacco streak virus (TSV) under greenhouse conditions during September to November 2005

\begin{tabular}{|c|c|c|c|}
\hline \multirow[b]{2}{*}{$\begin{array}{l}\text { Section, species } \\
\text { (ICG no. })^{\mathbf{b}}\end{array}$} & \multirow[b]{2}{*}{$\begin{array}{c}\text { No. of plants } \\
\text { tested }\end{array}$} & \multicolumn{2}{|c|}{ Mean percent infection ${ }^{a}$} \\
\hline & & $\begin{array}{l}\text { Inoculated } \\
\text { leaves }\end{array}$ & $\begin{array}{c}\text { Subsequently produced } \\
\text { leaves }\end{array}$ \\
\hline \multicolumn{4}{|l|}{ Arachis batizocoi } \\
\hline 8124 & 8 & $100(1.5)$ & $75(0.98)$ \\
\hline 8209 & 2 & $100(1.5)$ & $50(0.75)$ \\
\hline \multicolumn{4}{|l|}{ A. cardenasii } \\
\hline 11562 & 5 & $100(1.46)$ & $25(0.27)$ \\
\hline 11564 & 9 & $90(1.18)$ & $77.5(0.89)$ \\
\hline 11566 & 10 & 90 (1.17) & $60(0.64)$ \\
\hline 12165 & 7 & $29(0.3)$ & $87.5(1.21)$ \\
\hline \multicolumn{4}{|l|}{ A. duranensis } \\
\hline 8123 & 10 & $100(1.41)$ & $80(0.93)$ \\
\hline 8139 & 4 & $50(0.52)$ & $0(0.01)$ \\
\hline 8195 & 9 & $57.5(0.63)$ & $0(0.01)$ \\
\hline 8200 & 9 & $35(0.36)$ & $0(0.01)$ \\
\hline 8203 & 9 & $90(1.18)$ & $0(0.01)$ \\
\hline 8205 & 7 & $60(0.82)$ & $12.5(0.13)$ \\
\hline 11550 & 7 & $29(0.3)$ & $0(0.01)$ \\
\hline \multicolumn{4}{|l|}{ A. stenosperma } \\
\hline 8137 & 6 & $66.5(0.89)$ & $100(1.51)$ \\
\hline 13171 & 10 & $80(0.93)$ & $70(0.79)$ \\
\hline 13172 & 10 & $40(0.41)$ & $40(0.41)$ \\
\hline 13210 & 7 & $46(0.49)$ & $0(0.01)$ \\
\hline 13223 & 7 & $29(0.3)$ & $29.2(0.3)$ \\
\hline 13233 & 4 & $50(0.52)$ & $0(0.01)$ \\
\hline \multicolumn{4}{|l|}{ A. villosa } \\
\hline 8144 & 4 & $0(0.01)$ & $0(0.01)$ \\
\hline 13168 & 4 & $25(0.26)$ & $50(0.52)$ \\
\hline \multicolumn{4}{|c|}{ Control (A. hypogaea) } \\
\hline JL 24 & 10 & $70(0.79)$ & $90(1.25)$ \\
\hline K 1375 & 10 & $70(0.79)$ & $50(0.53)$ \\
\hline $\operatorname{SEM}( \pm)^{\mathrm{c}}$ & $\ldots$ & $(0.22)$ & $(0.21)$ \\
\hline $\operatorname{LSD}(P=5 \%)^{\mathrm{d}}$ & $\ldots$ & $(0.64)$ & $(0.64)$ \\
\hline
\end{tabular}

${ }^{\text {a }}$ Percent infection based on virus detection in enzyme linked-immunosorbent assay. Numbers in parenthesis $=$ angular transformed values.

${ }^{\mathrm{b}}$ ICG = International Crops Research Institute for the Semi-Arid Tropics groundnut accession number.

${ }^{\mathrm{c}} \mathrm{SEM}=$ standard error of the mean

${ }^{\mathrm{d}} \mathrm{LSD}=$ least significant difference.

were threefold higher than those of the healthy control samples. ELISA tests for TSV in inoculated leaves were done a week after inoculation, and tests were repeated at 2 -week intervals in newly emerged leaves until the plants were 3 months old. Individual replicated observations were converted to percentages and subjected to angular transformation by substituting $0 \%$ by $1 / 4 n$ and $100 \%$ by 100 $-1 / 4 n$, where $n$ is the plant number. Data were subjected to analysis of variance using the GenStat 9.1 statistical package (Lawes Agricultural Trust, Rothamsted Experimental Station, England). Least significant differences at a 5\% level of significance were used to test the differences among accessions.
RESULTS

The inoculated leaves of the 56 Arachis accessions developed chlorotic or necrotic patches and tested positive to TSV in ELISA (data not shown). The susceptible wild Arachis accessions developed systemic symptoms within 20 to 30 days post inoculation. Symptoms on these accessions were similar to those in cultivated peanut, such as leaf chlorosis followed by necrosis of leaves, petioles, and stems, and premature death of plants within 6 weeks post inoculation. Asymptomatic infection, delayed symptom expression, or symptom remission was not observed in the tested wild Arachis accessions. Percent infection in controls as well as test accessions reached a maximum level by 60 days after inoculation. In ELISA, only symptomatic plants were positive for TSV and all the asymptomatic plants were negative. The susceptible controls (peanut cvs. JL 24 and $\mathrm{K} 1375$ ) had 50 to $100 \%$ infection, and typical TSV symptoms developed 12 to 20 days post inoculation (Tables 1, 2, and 3). The absorbance at $405 \mathrm{~nm}$ values of TSVpositive samples ranged between 1.5 and 3.0 and were less than 0.3 for uninfected and healthy control plants (data not shown).

Of the 56 accessions initially evaluated, 12 had no systemic infection (Table 1 ). Eight of these accessions (ICRISAT groundnut accession [ICG] nos. 8195, $8200,8205,8209,11550,11552,12165$, and 13210) were completely free from infection in both inoculated and subsequently emerged leaves. Virus was detected in inoculated leaves of four accessions (ICG nos. 8144, 8139, 13171, and 13168), but not in subsequently emerged leaves (Table 1). Among the remaining 44 accessions, infection in inoculated and systemic leaves ranged between 0 and $100 \%$ (Table 1). In four accessions (ICG nos. 8123, 8124, 8137, and 8203) virus was not detected in inoculated leaves; however, systemic infection was observed in 10 to $30 \%$ of these plants. This indicates a lack of correlation between virus in inoculated leaves and systemic infection. Moreover, the reactions of some genotypes were not consistent during reevaluations despite using similar plant growth and inoculation conditions (Table 2). For instance, during the first trial, ICG nos. 8124,8137 , and 12165 had less than $16 \%$ systemic infection whereas, in the second trial, the infection rate was greater than $70 \%$, (Tables 1 and 2). Because of this situation, emphasis was placed on repeated testing of promising accessions in order to select accessions that had consistent resistance to systemic TSV infection.

All the accessions that had less than $35 \%$ systemically infected plants in the 2004 experiment were reevaluated during 2005; however, ICG nos. 8186, 13257, and 11552 were not retested due to nonavailability of seed (Table 2). All the resistant 
accessions belong to section Arachis. Between 0 and $100 \%$ of the plants in each of the 21 accessions that were evaluated during 2005 became systemically infected (Table 2). None of the plants of ICG nos. $8139,8144,8195,8200,11550$, and 13210 had systemic infections in either 2004 or 2005 (Tables 1 and 2). In addition, systemic infection was not observed in ICG nos. 8203 and 13233, which had 30 to $33 \%$ systemically infected plants in 2004. In the 2005 trial, only ICG no. 8144 was free of TSV infection in both inoculated and subsequently emerged leaves. Surprisingly, accessions ICG nos. 8209, 12165, 13171, and 13168 , which had no systemic infection during the earlier trial, had 50 to $87.5 \%$ systemically infected plants in the second screening (Table 2).

Seven accessions (ICG nos. 8139, 8195, $8200,8203,8205,11550$, and 13210) that had 0 to $35 \%$ infection in the first two trials were evaluated during 2006 (Table 3). ICG 8144 and ICG 13233, which had 0 to $33 \%$ systemic infection during the first two trials, were not tested due to seed limitation. TSV was not detected in the systemic leaves of any of these accessions even though TSV was detected in 24 to $81 \%$ of inoculated leaves. The lack of systemic infection in repeated trials, despite the fact that some of these plants were positive to TSV infection in inoculated leaves, demonstrated consistent systemic resistance reactions to TSV (Table 3).

\section{DISCUSSION}

The viruses that have been recognized as economically important on peanut worldwide are Cucumber mosaic virus, Cowpea mild mottle virus, Groundnut ringspot virus, Peanut bud necrosis virus (PBNV), Peanut stripe virus, Peanut clump virus, Indian peanut clump virus, Peanut mottle virus, Peanut stunt virus, Tomato spotted wilt virus (TSWV), and groundnut rosette disease virus complex (22). Although TSV occurrence on peanut has been reported from Brazil (4) and South Africa (2), the virus was less prevalent and less important in Brazil, and was detected on only two peanut plants in South Africa, where it was described to cause chlorosis and malformed growth of young leaves (2). In contrast, TSV has emerged as a major production constraint on peanut in India. Reasons for such severe TSV epidemics are not known. Due to lack of effective TSV resistance in peanut cultivars, wild Arachis spp. were evaluated to identify sources of resistance that could be used in breeding programs.

The genus Arachis consists of 69 species placed under nine sections (10). The ICRISAT gene bank holds 452 accessions of 42 wild Arachis spp. representing eight sections $(9,14)$. In the present study, 56 wild accessions were evaluated for TSV resistance (Table 1), followed by reevaluation of accessions that had lower incidence of systemic infection. Eight TSV resistant accessions were identified: ICG nos. 8139, 8200, 11550, 8195, 8203, and 8205 belonging to $A$. duranensis; ICG 13210 belonging to A. stenosperma; and ICG 8144 belonging to A. villosa. Although these genotypes are yet to be evaluated under field conditions in TSVendemic areas, we hypothesize that the resistance will be effective against natural infection because the accessions were challenged with a high dosage of virus inoculum. Moreover, selection of genotypes with TSV resistance based on the genotype performance under natural occurrence of the disease in the field was precluded by the fact that TSV occurrence is sporadic and difficult to predict under the field situations. Our previous field trials to identify TSV resistance in peanut varieties, conducted during the 2001-03 rainy seasons (June to November) at Kadiri and
Raichur, Andhra Pradesh, were inconclusive due to low natural incidence in the experimental plots (R. D. V. J. Prasadarao, unpublished data). Under such conditions, all plants may not be exposed to TSV inoculum; therefore, the level of true resistance cannot be assessed based on field observations only. Several studies have shown that experimental transmission of virus by mechanical sap inoculation or using viruliferous vectors under greenhouse conditions is effective to evaluate the level of resistance in a genotype by ensuring uniform inoculum pressure and growth conditions $(13,16,24)$. In addition, Mandal et al. (16) reported that genotypes such as Georgia Green that are susceptible to TSWV by mechanical inoculation showed effective resistance against thripsborne inoculum under field conditions. Reddy et al. (24) reported that, of seven wild Arachis accessions that were field resistant to thrips-borne PBNV inoculum, only three accessions were resistant to PBNV when tested by mechanical sap inoculations under greenhouse conditions. These examples indicate the robustness of the mechanical inoculation method for evaluating virus resistance in peanut genotypes.

We found that mechanical transmission of TSV from peanut to peanut was relatively difficult and often resulted in a significant number of escapes. A similar situation was reported with TSWV transmission from peanut to peanut (15). To enhance the transmission efficiency, we investigated the factors influencing the mechanical transmission of TSV to peanut and found that (i) serial passage of virus by mechanical transmission onto peanut or other susceptible herbaceous hosts resulted in attenuation of symptoms; (ii) transmission of TSV from peanut to peanut resulted in less than $60 \%$ infection, but 70 to $100 \%$ infection was obtained when the virus was

Table 3. Response of Tobacco streak virus (TSV)-resistant wild Arachis accessions to artificial inoculation with TSV under greenhouse conditions during May to July 2006

\begin{tabular}{|c|c|c|c|c|c|c|}
\hline \multirow[b]{3}{*}{ Section, species (ICG no.) $)^{b}$} & \multicolumn{3}{|c|}{ Trial Ia } & \multicolumn{3}{|c|}{ Trial II ${ }^{\mathbf{a}}$} \\
\hline & \multirow[b]{2}{*}{$n$} & \multicolumn{2}{|c|}{ Mean percent infection } & \multirow[b]{2}{*}{$n$} & \multicolumn{2}{|c|}{ Mean percent infection } \\
\hline & & Inoculated leaves & Subsequently produced leaves & & Inoculated leaves & Subsequently produced leaves \\
\hline \multicolumn{7}{|l|}{ Arachis duranensis } \\
\hline 8139 & 10 & $72(0.88)$ & $0(0.009)$ & 8 & $0(0)$ & $0(0)$ \\
\hline 8195 & 17 & $36(0.37)$ & $0(0.003)$ & NT & NT & NT \\
\hline 8200 & 19 & $29(0.3)$ & $0(0.003)$ & 9 & $55(0.58)$ & $0(0)$ \\
\hline 8203 & 10 & $23.75(0.25)$ & $0(0.002)$ & NT & NT & NT \\
\hline 8205 & 16 & $23.5(0.24)$ & $0(0.002)$ & NT & NT & NT \\
\hline 11550 & 17 & $43.75(0.46)$ & $0(0.004)$ & 6 & $0(0)$ & $0(0)$ \\
\hline \multicolumn{7}{|l|}{ A. stenosperma } \\
\hline 13210 & 16 & $81(1)$ & $0(0.009)$ & NT & NT & NT \\
\hline \multicolumn{7}{|l|}{ A. hypogaea } \\
\hline JL 24 & 20 & $67.5(0.75)$ & $60(0.007)$ & 20 & $40(0.416)$ & $80(0.937)$ \\
\hline $\operatorname{SEM}( \pm)^{\mathrm{c}}$ & $\ldots$ & $(0.12)$ & $(0.001)$ & $\ldots$ & $(0.0432)$ & $(0.0353)$ \\
\hline $\operatorname{LSD}(P=5 \%)^{\mathrm{d}}$ & $\ldots$ & $(0.35)$ & $(0.003)$ & $\ldots$ & $(0.1381)$ & $(0.1128)$ \\
\hline
\end{tabular}

a Percent infection based on virus detection in enzyme-linked immunosorbent assay, $n=$ number of plants tested, number in parenthesis $=$ angular transformed values, and NT $=$ not tested.

${ }^{\mathrm{b}}$ ICG = International Crops Research Institute for the Semi-Arid Tropics groundnut accession number.

c $\mathrm{SEM}=$ standard error of the mean.

${ }^{\mathrm{d}} \mathrm{LSD}=$ least significant difference. 
transmitted from French bean to peanut; (iii) use of various combinations of antioxidants, abrasives, and inoculation methods did not significantly affect infectivity; and (iv) day temperatures of greater than $40^{\circ} \mathrm{C}$ (April to May) and night temperatures of less than $15^{\circ} \mathrm{C}$ (December) significantly reduced infectivity and symptom expression (data not presented). Based on these observations, the mechanical sap inoculation conditions (described in this study) were optimized for evaluation of TSV resistance in the Arachis germplasm by administering a large dosage of virus inoculum under greenhouse conditions. This procedure usually resulted in more than $80 \%$ transmission rate in highly susceptible cultivars such as JL 24 (Tables 1, 2 , and 3). In the susceptible cv. K 1375, only 50 and $70 \%$ of the plants were infected in two experiments (Tables 1 and 2). However, this accession was regarded as highly susceptible to TSV as per the criteria set in this study ( $>35 \%$ infected plants). The most likely explanation for the variability in TSV transmission rates of highly susceptible cultivars such as JL 24 and K 1375, and even in wild Arachis accessions could be escapes. For this reason, emphasis has been placed on repeated testing of promising accessions to assess the virus resistance. All eight resistant accession selected had consistent resistant responses across all three trials.

Differences in virus infection in the inoculated leaves and subsequently emerged leaves was observed in susceptible controls and test plants. On a few occasions, higher incidence of systemic infection compared with the inoculated leaves was observed. For instance, virus was detected in the inoculated leaves of 40 and $50 \%$ of the systemically infected JL 24 and ICG 8208, respectively (Table 1 ). This could be due to low virus concentration in the inoculated leaves that were undetectable by ELISA at 1 week post inoculation. This is likely because virus was detected in such leaves when retested 2 weeks after inoculation (data not presented). However, at 2 weeks post inoculation, inoculated leaves of most of the test plants were senesced or damaged due to necrosis, precluding routine testing. In most cases, the incidence of infection in inoculated and systemic leaves was similar $(100 \%$ infection in ICG nos. 8135,8198 , and $11563 ; 16.5 \%$ in 11564 ; and $80 \%$ in 11563 ; Table 1) or higher in inoculated leaves (ICG nos. 8206 and 8199; Table 1); therefore, the data suggest that virus reaches adequate concentration in inoculated leaves by 1 week post inoculation to provide for systemic movement in susceptible accessions.

Accessions from the same species varied in their reactions to TSV. For instance, 6 of 16 A. duranensis accessions evaluated were resistant to TSV (Table 1). These differences in disease reaction may be due to genetic variation within the species, as has been observed earlier in wild Arachis spp. $(18,24,27)$. In most of the resistant accessions, virus multiplication was detected in inoculated leaves, suggesting that the resistance mechanism results from a block to systemic spread of the virus. Grafting experiments, which were not done in this study, could provide information on whether any of these genotypes were immune to TSV infection (3). A similar mechanism (that is, lack of systemic spread of virus from inoculated leaves in spite of repeated mechanical sap inoculations) was reported for PBNV resistance in wild Arachis germplasm (24).

The resistant accessions ICG nos. 8139 and 11550 also possess high levels of resistance to rust (Puccinia arachidis) and late leaf spot (Phaeoisariopsis personata) (18) and ICG no. 8144 to Peanut bud necrosis virus (24) Thus, these accessions possess resistance to multiple pathogens and might be used to develop multiple disease-resistant peanut cultivars through interspecific breeding programs. All the TSV-resistant accessions are in section Arachis, have an 'A-genome' in common with the cultivated peanut, and are cross compatible with A. hypogaea. Seed of resistant accessions are available at the ICRISAT gene bank for utilization in breeding programs. Earlier studies have used accessions from section Arachis in conventional breeding programs to transfer resistance to rust and late leaf spot into agronomically elite cultivars $(17,26)$. Therefore, there is a potential to transfer TSV resistance into widely adapted peanut cultivars. Work has been initiated at ICRISAT to develop interspecific hybrids using ICG nos. 8139 and 8144 for TSV resistance. To our knowledge, this is the first report of identification of resistance to TSV in wild Arachis germplasm.

\section{ACKNOWLEDGMENTS}

This work was funded under National Agricultural Technology Project (NATP)-PSR Project ROPS-18 by the Indian Council of Agricultural Research, New Delhi, India.

\section{LITERATURE CITED}

1. Bhat, A. I., Jain, R. K., Kumar, A., Ramiah, M., and Varma, A. 2002. Serological and coat protein sequence studies suggest that necrosis disease on sunflower in India is caused by strain of Tobacco streak ilarvirus. Arch. Virol. 147:651-658.

2. Cook, G., deMiranda, J. R., Roossinck, M. J., and Pietersen G. 1999. Tobacco streak ilarvirus detected on groundnut in South Africa. Afr. Plant Prot. 5:13-19.

3. Cooper, J. I., and Jones, A. T. 1983. Reponses of plants to viruses: Proposals for the use of terms. Phytopathology 73:127-128.

4. Costa, A. S., and Carvalho, A. M. B. 1961. Studies on Brazilian tobacco streak. Phytopathol. Z. 42:113-138

5. FAO 2005. FAOSTAT Data. http://www.fao stat.fao.org/.

6. Hobbs, H. A., Reddy, D. V. R., Rajeswari, R., and Reddy, A. S. 1987. Use of direct antigen coating and protein A coating ELISA procedures for detection of three peanut viruses. Plant Dis. 71:747-749.
7. Jain, R. K., Bag, S., and Awasthi, L. P. 2005. First report of natural infection of Capsicum annuum by Tobacco streak virus in India. Plant Pathol. 54:257.

8. Kalyani, G., Sonali, S., Reddy, A. S., Reddy, A. G. S., Waliyar, F., and Nigam, S. N. 2005 Resistance to tobacco streak virus in groundnut, Arachis hypogaea. J. Oilseeds Res. 22:105-107.

9. Kameswara-Rao, N. K., Reddy, L. J., and Bramel, P. J. 2003. Potential of wild species for genetic enhancement of some semi-arid food crops. Genetic Res. Crop Evol. 50:707721.

10. Krapovikas, A., and Gregory, W. C. 1994 Taxonomia del genero Arachis (Leguminosae). Bonplandia 8:1-86.

11. Krishnareddy, M., Devaraj, Lakshmi Raman, Salil Jalali, and Samuel, D. K. 2003.Outbreak of Tobacco streak virus causing necrosis of cucumber (Cucumis sativus) and gherkin ( $\mathrm{Cucu}$ mis anguria) in India. Plant Dis. 87:1264.

12. Kumar, A. N., Lakshmi Narasu, M., Zehr, U. B., and Ravi, K. S. 2006. Natural occurrence and distribution of Tobacco streak virus in South India. Indian J. Plant Prot. 34:54-58.

13. Kumar, P. L., Latha, T. K. S., Kulkarni, N. K., Raghavendra, K., Saxena, K. B., Waliyar, F., Rangaswamy, K. T., Muniyappa, V., Dorisway, S., and Jones, A. T. 2005. Broad-based resistance to pigeonpea sterility mosaic disease in wild relatives of pigeonpea (Cajanus: Phaseoleae). Ann. App. Biol. 146:371-379.

14. Mallikarjuna, N. 2003. Wide hybridization in important food legumes. Pages 155-171 in Improvement Strategies for Leguminosase Biotechnology. P. K Jaiwal. and R. P. Singh, eds. Kluwer Academic Publishers, UK

15. Mandal, B., Pappu, H. R., and Culbreath, A. K. 2001. Factors affecting mechanical transmission of Tomato spotted wilt virus to peanut (Arachis hypogaea). Plant Dis. 85:12591263.

16. Mandal, B., Pappu, H. R., Culbreath, A. K., Holbrook, C. C., Gorbet, D. W., and Todd, J. W. 2002. Differential response of selected peanut (Arachis hypogaea) genotypes to mechanical inoculation by Tomato spotted wilt virus. Plant Dis. 86:939-944.

17. Moss, J. P., Singh, A. K., Reddy, L. J., Nigam, S. N., Subrahmanyam, P., McDonald, D., and Reddy, A. G. S. 1997. Registration of ICGV 87165 peanut germplasm line with multiple resistance. Crop Sci. 37:1028.

18. Pande, S., and Narayana Rao, J. 2001. Resistance of wild Arachis species to late leaf spot and rust in greenhouse trials. Plant Dis. 85:851-855.

19. Prasada-Rao, R. D. V. J., Reddy, A. S. Chander Rao, S., Varaprasad, K. S., Thirumala-Devi, K., Nagaraju., Muniyappa, V., and Reddy, D. V. R. 2000. Tobacco streak ilarvirus as causal agent of sunflower necrosis disease in India. J. Oilseeds Res. 17:400-401.

20. Prasad-Rao, R. D. V. J., Reddy, A. S., Reddy, S. V., Thirumala-Devi, K., Chander-Rao, S. Manoj Kumar, V., Subramanyam, K., Yellamanda Reddy, T., Nigam, S. N., and Reddy, D. V. R. 2003. The host range of Tobacco streak virus in India and transmission by thrips. Ann. Appl. Biol.142:365-368.

21. Prasada-Rao, R. D. V. J., Reddy, D. V. R., Nigam, S. N., Reddy, A. S., Waliyar, F., Yellamanda Reddy, T., Subramniam, K., John Sudheer, M., Naik, K. S. S., Bandopadhyay, A. Desai, S., Ghewande, M. P., Basu, M. S., and Somasekhar. 2003. Peanut Stem Necrosis: A New Disease of Groundnut in India. Information Bulletin No. 67. International Crops Research Institute for the Semi-Arid Tropics, Andhra Pradesh, India.

22. Reddy, D. V. R. 1991. Groundnut viruses and virus diseases: distribution, identification and control. Rev. Plant Pathol. 9:665-678. 
23. Reddy, A. S., Prasada-Rao, R. D. V. J., Thirumala-Devi, K., Reddy, S. V., Mayo, M. A., Roberts, I., Satyanarayana, T., Subramaniam, K., and Reddy, D. V. R. 2002. Occurrence of Tobacco streak virus on Peanut (Arachis hypogaea L.) in India. Plant Dis. 86:173-178.

24. Reddy, A. S., Reddy, L. J., Mallikarjuna, N., Abdurahman, M. D., Reddy, Y. V., Bramel, P. J., and Reddy, D. V. R. 2000. Identification of resistance to Peanut bud necrosis virus in wild Arachis germplasm. Ann. Appl. Biol. 137:135139.

25. Shukla, S., Kalyani, G., Kulkarni, N., Waliyar, F., and Nigam, S. N. 2005. Mechanism of transmission of Tobacco streak virus by Scirtothrips dorsalis, Frankliniella schultzei and Megalurothrips usitatus in groundnut, Arachis hypogaea L. J. Oilseeds Res. 22:215-217.
26. Stalker, H. T., and Beute. M. K. 1993. Registration of four interspecific peanut germplasm lines resistant to Cercospora arachidicola. Crop Sci. 33:1117.

27. Subrahmanyam, P., Moss, J. P., McDonald, D., Subba Rao, P. V., and Rao, V. R. 1985. Resistance to leaf spot caused by Cercosporidium personatum in wild Arachis species. Plant Dis. 69:951-954. 